\title{
MOŽNOSTI VYUŽITÍ MIKROVLNNÉHO ZÁŘENÍ PRO URYCHLENÍ TUHNUTÍ SMĚSÍ TVOŘENÉ POJIVEM Z POLYMERNÍ MATRICE A PLNIVEM Z ODPADNÍCH TEPELNĚ IZOLAČNÍCH MATERIÁLŮ
}

\author{
POSSIBILITIES OF USING MICROWAVE RADIATION TO ACCELERATE \\ THE SOLIDIFICATION OF MIXTURES CONSISTING OF A POLYMER \\ MATRIX BINDER AND A WASTE THERMAL INSULATION FILLER
}

\author{
David Průša ${ }^{*}, 1$, Stanislav Št’astník ${ }^{1}$, Karel Šuhajda ${ }^{1}$
}

\author{
*David.Prusa@vutbr.cz \\ ${ }^{1}$ Fakulta stavební VUT v Brně, Veveři 331/95, 60200 Brno
}

\begin{abstract}
Abstrakt
Předložená práce se zabývá možností využití působení mikrovlnného záření na čerstvé směsi tvořené plnivem z odpadního tepelně izolačního expandovaného polystyrénu a pojivem z polymerní směsi pro urychlení doby potřebné pro zpevnění. Experimentálně byl vyzkoušen vliv doby působení mikrovlnného záření na hodnotu součinitele tepelné vodivosti vlastnosti směsí.
\end{abstract}

\section{Klíčová slova}

Mikrovlnné záření, polymery, recyklace, polystyrény

\begin{abstract}
The presented work deals with the possibility of using the action of microwave energy on fresh mixtures consisting of a filler from waste thermal insulation expanded polystyrene and a binder from a polymer mixture to accelerate the time required for the mixture to solidify. The influence of microwave exposure time on thermal engineering material properties of mixtures was experimentally tested.
\end{abstract}

Key words

Microwave radiation, polymers, recycling, polystyrene

\section{1 ÚVOD}

Předložená práce se zabývá možností použití mikrovlnného záření pro polymerizaci vhodného pojiva, které stabilizuje drt' odpadního pěnového polystyrénu při př́ípravě lehké tepelně izolační hmoty $\mathrm{s}$ využitím ve stavebnictví. Při zásypech dutin ve stavbách partikulárními látkami postupně dochází k jejich sesedání, a je pouze otázkou času, kdy se v dutinách vytvoří nevyplněný volný prostor. Otázka stabilizace zrn v násypu partikulárních částic je tak klíčová.

V současné době se daří dostupnými technologiemi poměrně „,̌istě“ separovat partikulární částice odpadních vypěněných plastů a tyto pak využít pro přípravu výrobků znovu použitelných ve stavebnictví, které využívají zejména příznivých užitných vlastností odpadních surovin. U vypěněných plastů se jedná hlavně o jejich nízkou objemovou hmotnost, př́iznivou soudržnost a nízkou hodnotu součinitele tepelné vodivosti. $Z$ toho důvodu se využití odpadních vypěněných plastů jako suroviny pro přípravu tepelně izolačních hmot jeví velmi příznivě.

Rozsah použití hmot ve stavebnictví na bázi stabilizovaných partikulárních částic spojených vhodným polymerním pojivem může být široký, patrně nejpř́íznivějšími produkty jsou desky o konstantní tloušt'ce. U deskových izolantů se očekává nejen jejich př́iznivý tepelný odpor v celém jejich objemu konstantní, ale také nízká objemová hmotnost a dostatečná tlaková pevnost. Mezi dalšími požadovanými užitnými vlastnostmi je 
vhodná pórovitost z hlediska zajištění větrotěsnosti materiálové vrstvy, tvarová stálost i odolnost proti vlivům působícím z okolí pro zajištění dlouhodobé životnosti produktu.

Z hlediska tzv. ekologické stopy se mohou uvedené výrobky vyznačovat minimální zátěží pro životní prostředí, a to jak v ohledu použitých odpadních surovin, tak i z hlediska technologie jejich stabilizace.

\section{Použité pojivo}

Selekce vhodného pojiva vychází z předpokladu využití polymeru, který životnímu prostředí nepřináší škodlivou zátěž. Proto byla zvolena polyvinylacetátová báze ve formě lepidla (dostupné pod obchodním názvem Duvilax).

Principem jeho výroby je polymerace vinylacetátu. Jedná se o chemický postup, kdy je ve vodné fázi monomer emulgován a procesem polymerace pak přeměněn na polymer. Uvedené polymery jsou vysokomolekulární látky, které se v průmyslu široce uplatňují. Běžně se využívají pro výrobu kopolymerních vinylakrylátů a také mohou být použity $\mathrm{v}$ potravinářství jako ochrana před plísněmi i vlhkostí. V alkalickém prostředí ale dochází $\mathrm{k}$ jejich rozkladu za tvorby kyseliny octové.

Mají poměrně nízkou viskozitu (sušina kolem 50 \%), takže je lze většinou použít bez úpravy. Vytvrzují za normální teploty fyzikálním pochodem odpařování vody - voda z disperze difunduje do okolního pórovitého materiálu, např. do dřeva při jeho lepení - lepidlo se koncentruje a gelovatí. Doba lisování je asi 1 hodina při tlaku $0,5 \mathrm{MPa}$. Lepidlo není vodovzdorné, má slabě kyselou reakci s hodnotou pH 4-6, což je nutno při lepení vzít $\mathrm{v}$ úvahu.

Emulze PVA ve vodě se používá jako lepidlo na porézní materiály; lepidlo neobsahuje organická rozpouštědla, je nehořlavé, ředitelné vodou a zdravotně nezávadné. Je schváleno Státním zdravotním ústavem jako nezávadné lepidlo vhodné pro styk s potravinami.

\section{Účinky mikrovlnného záření}

Mikrovlny patří do široké rodiny elektromagnetických vlnění, zahrnující rovněž oblast viditelného světla, které se řídí Maxwellovými rovnicemi. Platí pro ně, že vektory charakterizující magnetické a elektrické pole jsou v každém bodě a v každém okamžiku k sobě kolmé a oba jsou kolmé ke směru pohybu vlny. Jejich amplitudy mají konstantní poměr a ve vakuu se elektromagnetické vlny pohybují rychlostí světla, takže platí vztah:

$$
c=l \cdot f \text {, }
$$

kde $c$ je rychlost světla ve vakuu, $l$ je vlnová délka, $f$ je vlnová frekvence.

Mikrovlnným zářením se rozumí elektromagnetické záření o frekvenci od $300 \mathrm{MHz}$ do $300 \mathrm{GHz}$, což odpovídá vlnové délce od $1 \mathrm{~m}$ do $1 \mathrm{~mm}$, zaujímající oblast mezi infračerveným zářením a rádiovými vlnami. Většina frekvencí v tomto intervalu se použíá ke komunikačním účelům, a aby se zabránilo vzájemnému rušení, byla pro mikrovlnný ohřev vymezena frekvence $2,45 \mathrm{MHz}$, která odpovídá délce vlny $12,2 \mathrm{~cm}$.

Mikrovlny se můžou šírit v různých médiích, samozřejmě s nižší rychlostí než ve vakuu. Ve vzduchu je tento rozdíl malý, ale jiná je situace ve vodě, kde se mikrovlny šiří devětkrát nižší rychlostí, a v důsledku toho se i vlnová délka devětkrát zkrátí na $1,36 \mathrm{~cm}$. Přri přechodu mikrovln z jednoho prostředí do druhého dochází na rozhraní k odrazovým a lomovým jevům stejně jako u světla. V podstatě jde o kombinaci tří prrípadů - část energie mikrovln se od povrchu odráží, část v látce absorbuje a část materiálem prochází.

Při absorpci mikrovln v materiálu se snižuje amplituda vlny. Míra absorpce je charakterizována pomocí penetrační hloubky, což je vzdálenost, kterou mikrovlnné záření v materiálu musí projít, aby jeho intenzita klesla na $13,53 \%$ původní hodnoty.

Pokud použijeme k popisu mikrovln de Broglieho vztah, zjistíme, že na ně lze pohlížet také jako na částice s energií $0,00001 \mathrm{eV}$, což je energie velmi malá a nestačí ani k rozbití nejslabší chemické vazby. Odtud tedy schopnost mikrovln ohřívat neplyne. Pro ohřev se využívá jevu, kdy permanentní dipóly se v stejnosměrném elektrickém poli orientují do energeticky nejpřijatelnější polohy.

Pokud dojde k přeplování pole, snaží se molekuly nesoucí náboj opět otočit do nejvhodnější pozice. Snaha vyrovnat se s měnícím se elektrickým polem mikrovln vede k rotačnímu pohybu, při němž dochází ke kolizím a tření se sousedními molekulami a ke vzniku tepla. Nejběžnější molekulou, jejíž permanentní dipólový moment vede $\mathrm{k}$ její rotaci při ozařování mikrovlnami je voda, která je zároveň ve značném množství přítomna v biologických materiálech a způsobuje tak jejich ohřev v mikrovlnné troubě [1], [2], [3].

\section{PRINCIP MIKROVLNNÉHO VYSOUŠENÍ}

Vystaví-li se ohřívaný materiál vysokofrekvenčnímu elektromagnetickému poli, uplatní se u polárních molekul frikční jev; zvyšuje se vnitřní energie molekul, čímž se materiál postupně ohřívá. Pří dokonalém mikrovlnném 
ohřevu je rozložení intenzity mikrovlnného pole zcela rovnoměrné a teplo vzniká stejnoměrně v celém objemu materiálu. Výskyt vlnění je závislý na konstrukci zařízení a na materiálech uvnitř ohřívací komory. Míra absorbovaného výkonu záleží na velikosti, tvaru a na permitivitě látky. Kromě samotného předmětu je důležitá zejména frekvence a intenzita elektromagnetického pole. U řady materiálů je relativní permitivita závislá také na teplotě, ale většinou permitivita narůstá s frekvencí. Teplo, které se v ohřívaných objektech generuje, se prostupem tepla šírí do okolí. Pokud ale ponecháme mikrovlnnou energii na materiál působit př́liš dlouho, může dojít $\mathrm{k}$ přehřátí a posléze $\mathrm{k}$ poškození struktury ohřívaného předmětu.

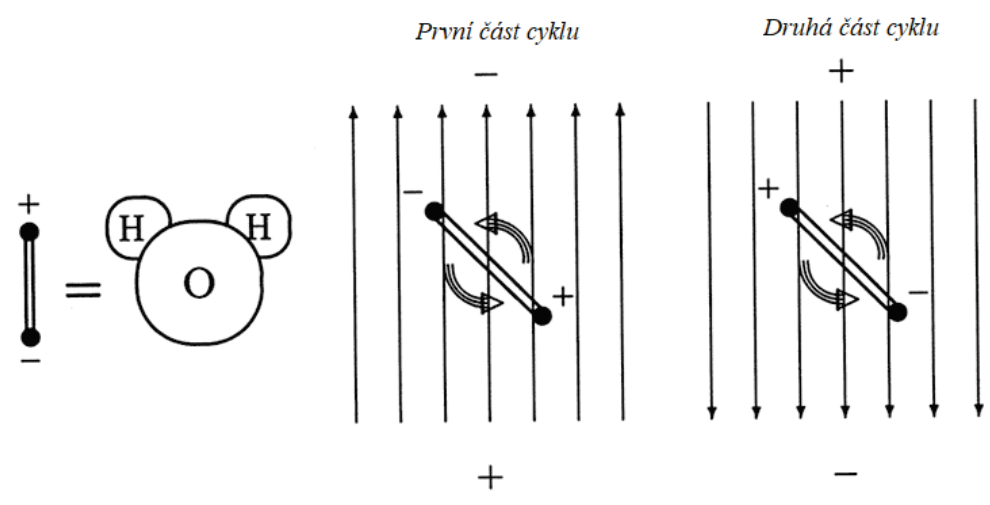

Obr. 1 Schéma molekuly vody, na kterou působí mikrovlnné záření [1].

Mezi výhody mikrovlnného záření patří zejména tzv. selektivní ohřev. Ohřŕvá se pouze složka, která absorbuje větší množství elektromagnetické energie (většinou se jedna o volně vázanou vodu). Takto se zajistí ohřátí vrstvy materiálu do větší hloubky. Tato ohřátá složka pak dále ohřívá další části materiálu.

Mikrovlnami lze prohřát materiál účinněji než pouhým ohřevem od povrchu, proto se tato technika použivá k vysoušení různých materiálů. S tím souvisí i případné urychlení vytvrzení čerstvých pojivových směsí, jak je popsáno v tomto příspěvku dále. Zkoumá se optimální výkon zdroje mikrovlnného záření a doba jeho působení s cílem najít variantu, při které je krystalová mř́žka pojivové složky směsi co nejméně poškozena.

Nevýhodou je již zmíněná vyšší energetická náročnost, v př́ipadě cementových kompozitních materiálů pak jiné mechanické vlastnosti a možná lokální přehřátí v důsledku mikrovlnného pole i samotného materiálu. V neposlední řadě pak figuruje požadavek na odbornou zpo̊sobilost s EMW zářením [2], [3].

\section{Vysoušení čerstvých směsí}

Obecně je nutné polymer PVAC odvodnit, aby došlo k jeho polymeraci. K tomu lze zvolit jeden z vícero způsobů: proces volného odpařování vody z polymeru, metodu vakuování, nebo také např́klad působení tepla pro kompenzaci výparného tepla vody. Nezbytnou podmínkou je odvádění uvolněné vodní páry. V experimentu bylo ověřeno vysoušení účinkem mikrovlnného záření v kontrastu s volným odpařováním vody.

Průběh mikrovlnného vysoušení/vytvrzování lze rozdělit na čtyři úseky:

- Vlastní ohřev molekul vody spojený se sekundárním ohřevem materiálu.

- Odpařování vody obsažené v povrchové vrstvě materiálu.

- Zvětšení objemu vody v důsledku jejího ohřevu. Zvětšení objemu vede k růstu tlaku, který se šírí všemi směry, tedy i k povrchu vysoušeného materiálu, a způsobuje vytlačování ohřáté vody na povrch.

- V průběhu postupného chladnutí dochází k průběžnému odpařování vody, která je na povrchu materiálu. $\mathrm{V}$ důsledku rozdílu vlhkosti na povrchu a v hloubce, dochází k rozdílu tzv. parciálního tlaku, který zabezpečí transport vlhkosti na povrch. K odpařování vlhkosti z povrchu vysoušeného materiálu je potřeba značné teplo (výparné teplo kapaliny). V důsledku toho dochází k ochlazování povrchu vysoušeného materiálu i vzduchu v okolí.

Faktory ovlivňující rychlost vysoušení:

- gradient teploty,

- obsah vlhkosti v povrchové vrstvě,

- relativní vlhkost prostředí, které je v kontaktu s vysoušeným materiálem,

- schopnost materiálu distribuovat vodu $\mathrm{z}$ jádra $\mathrm{k}$ povrchu,

- povrchová úprava vysoušeného materiálu, 
- tepelná vodivost vysoušeného materiálu [2], [3].

\section{VYUŽITÉ SMĚSI Z ODPADNÍHO POLYSTYRÉNU}

Složení jednotlivých ověřovaných směsí je uvedeno v Tab. 1. Pro jejich přípravu bylo použito pojivo syntetický polymer - polyvinylacetát - a jako plnivo sloužil drcený polystyrén. Ten byl použit ve formě sférických polystyrénových granulí, přičemž se jednalo o běžný expandovaný polystyrén. Návrh směsi se řídil požadavkem na dosažení maximální pevnosti v tlaku při zachování nízké objemové hmotnosti. Z každé směsi byly vytvořeny vzorky, na nichž byly zkoumány uvedené vlastnosti. Cílem bylo optimalizovat vstupní materiály, a zejména zvolit minimální dávku pojiva při zachování dostatečné manipulační pevnosti, dosažení požadované konzistence čerstvé směsi a nízké objemové hmotnosti. Ke zhutňování směsí byl použit laboratorní vibrační stůl. Při použití polymeru byl polymer nejprve smíchán s vodou pro dosažení dostatečné konzistence a poté smíchán s plnivem.

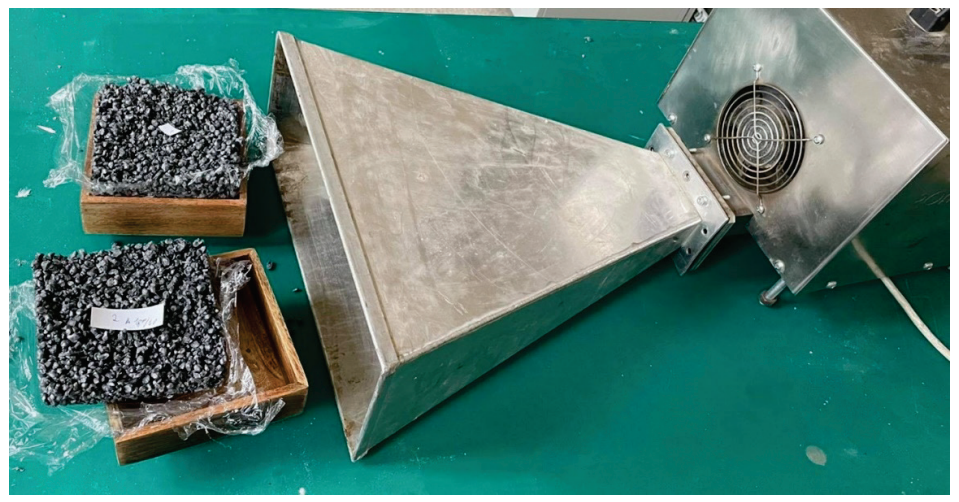

Obr. 2 Fotografie generátoru mikrovlnného záření a výsledných vzorků po procesu urychlení tvrdnutí zmíněných záměsí.

\section{Přehled složení jednotlivých záměsí a působení mikrovlnného záření}

Tab. 1 Přehled složení jednotlivých záměsí.

\begin{tabular}{cccc}
\hline Složka & Jednotka & $\mathbf{1}$ & $\mathbf{2}$ \\
\hline EPS & $\mathrm{kg} \cdot \mathrm{m}-3$ & 77 & 210 \\
Voda & $\mathrm{kg} \cdot \mathrm{m}-3$ & 616 & - \\
Polymer & $\mathrm{kg} \cdot \mathrm{m}-3$ & 307 & 780 \\
\hline
\end{tabular}

Tab. 2 Přehled časů působení mikrovlnného záření pro jednotlivé experimenty.

\begin{tabular}{|c|c|c|c|c|c|c|c|c|}
\hline \multirow{2}{*}{ Experiment } & \multicolumn{7}{|c|}{ Čas [s] } & \multirow{2}{*}{$\begin{array}{c}\text { Výkon } \\
{[W]}\end{array}$} \\
\hline & 1 & 2 & 3 & 4 & 5 & 6 & 7 & \\
\hline 1 & - & - & - & - & - & - & - & - \\
\hline 2 & 60 & 30 & 60 & 30 & 60 & 30 & 60 & 750 \\
\hline 3 & 300 & 60 & 300 & 60 & 300 & 60 & 300 & 750 \\
\hline
\end{tabular}

\section{VÝSLEDKY EXPERIMENTU゚}

Tab. 3 Přehled hodnot objemové hmotnosti, součinitele tepelné vodivosti a objemové tepelné kapacity naměřené u jednotlivých vzorků po 7 dnech od odformování.

\begin{tabular}{cccc}
\hline $\begin{array}{c}\text { Objemová } \\
\mathbf{h m o t n o s t}\left[\mathrm{kg} \cdot \mathbf{m}^{-3}\right]\end{array}$ & $\begin{array}{c}\text { Součinitel tepelné } \\
\text { vodivosti } \lambda\left[\mathbf{W} \cdot \mathbf{m}^{-1} \cdot \mathbf{K}^{-1}\right]\end{array}$ & $\begin{array}{c}\text { Objemová tepelná kapacita } \\
\mathbf{c} \cdot \rho^{\mathbf{b}}\left[\mathbf{J} \cdot \mathbf{m}^{-3} \cdot \mathbf{K}^{-1}\right]\end{array}$ \\
\hline 1.1 & 60 & 0,0362 & - \\
\hline
\end{tabular}




\begin{tabular}{cccc}
$\mathbf{1 . 2}$ & 60 & - & - \\
$\mathbf{1 . 3}$ & 60 & - & - \\
$\mathbf{2 . 1}$ & 50 & 0,0370 & $0,0969 \cdot 106$ \\
$\mathbf{2 . 2}$ & 50 & 0,0410 & $0,1769 \cdot 106$ \\
$\mathbf{2 . 3}$ & 50 & 0,0432 & $0,1981 \cdot 106$ \\
\hline
\end{tabular}

V př́ípadě prvního složení záměsi došlo k destrukci vzorků, nebot' se voda proměnila z kapalné fáze do fáze plynné př́liš rychle a porušila proces tuhnutí polymerního pojiva. Zkoušené vzorky se tak samovolně rozpadly.

Využité pojivo polyvinylacetát vodu obsahuje ve svém základu; je složeno ze sušiny (49 \%) a vody (51\%). Bylo tedy třeba navrhnout sadu nových směsí, ve kterých bylo množství vody redukováno. Výsledná záměs je označena jako 2 a obsahuje pouze vodu obsaženou v polymeru. Zde můžeme pozorovat vliv mikrovlnného záření na součinitel tepelné vodivosti záměsí tvořených převážně odpadním expandovaným polystyrénem.

V případě, že nebylo využito urychlení vytvrzení pomocí mikrovlnného záření, hodnota součinitele tepelné vodivosti je $0,0370 \mathrm{~W} \cdot \mathrm{m}^{-1} \cdot \mathrm{K}^{-1}$. Doba potřebná pro získaní manipulační pevnosti se pohybovala v rozmezí od 40 do $50 \mathrm{~h}$.

V př́ípadě využití mikrovlnného záření pro urychlení vytvrzení čerstvé směsi je pak hodnota součinitele tepelné vodivosti pro experiment č. $2 \lambda=0,0410 \mathrm{~W} \cdot \mathrm{m}^{-1} \cdot \mathrm{K}^{-1}$ a pro experiment č. $3 \lambda=0,0432 \mathrm{~W} \cdot \mathrm{m}^{-1} \cdot \mathrm{K}^{-1}$. Vzorky získaly během doby působení mikrovlnného záření potřebnou manipulační pevnost. Měření součinitele tepelné vodivosti ale proběhlo až po 48 hodinách od působení mikrovlnného záření na směs z důvodu omezení zkreslení měření součinitele tepelné vodivosti zvýšenou teplotou směsí.

Pozorujeme zde rapidní nárůst hodnoty součinitele tepelné vodivosti při různé době působení mikrovlnného záření oproti referenční záměsi, která tuhla za normálních podmínek.

Když mikrovlnné záření působilo na vzorek č. 2 a proběhl experiment č. 2, pak došlo k nárůstu hodnoty součinitele tepelné vodivosti přibližně o $10 \%$. V prŕípadě, kdy mikrovlnné záření působilo na vzorek č. 2, a proběhl experiment č. 3 , je nárůst hodnoty součinitele tepelné vodivosti přibližně o $15 \%$.

Spolu se součinitelem tepelné vodivosti byla měřena i objemová tepelná kapacita. Zde pozorujeme zvýšení hodnoty objemové tepelné kapacity při využití mikrovlnného vytvrzování přibližně na dvojnásobek.

Vyvstává tedy otázka, zda mikrovlnné záření narušuje mikrostrukturu polymerního pojiva během procesu tuhnutí, anebo degraduje prrímo plnivo zvolené záměsi, zde expandovaný polystyrén. To bude předmětem dalšího zkoumání.
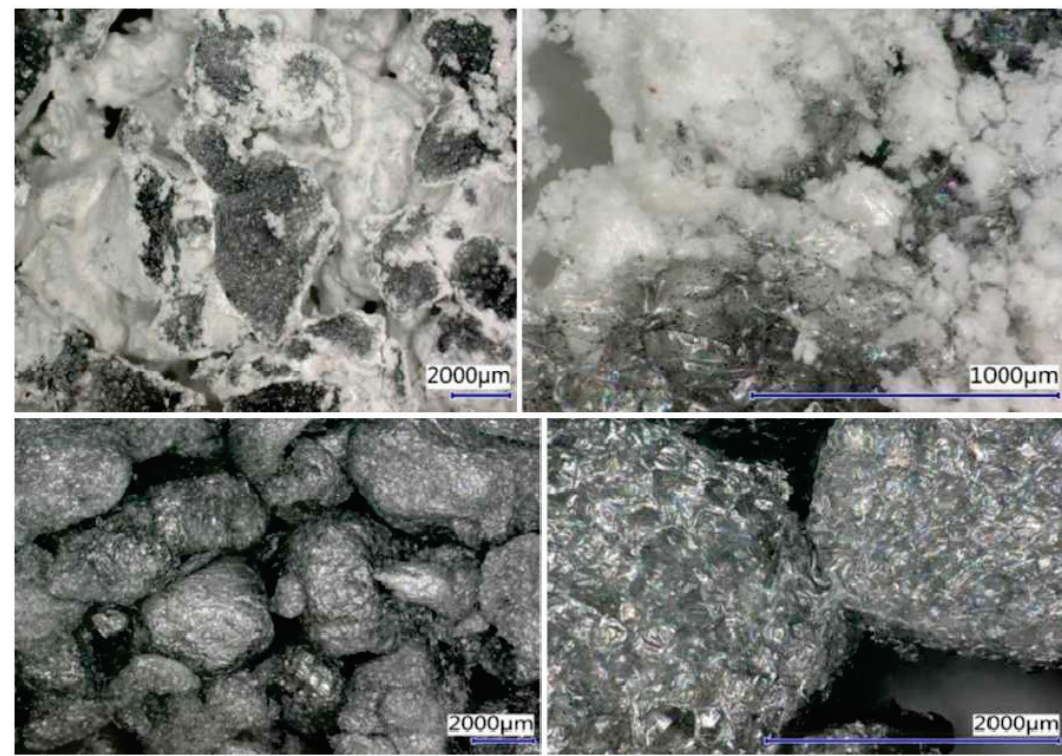

Obr. 3 Fotografie záměsí pod mikroskopem s různým zvětšením. 


\section{ZÁVĚR}

Mikrovlnným ohřevem, na rozdíl od jiných způsobů ohřevu, se zahřívá předmět objemově, nebot' tepelná energie se působením elektromagnetického vlnění produkuje poměrně rovnoměrně v celém objemu látky. Díky tomu lze regulovat teplotu. Spotřeba energie bývá přitom nižší a vytvrzovací čas pojiva kratší. Mikrovlnnou technologií lze zahřívat pouze konkrétní část produktu, a tak se maximalizuje účinnost procesu vytvrzování. Tím, podle prezentovaných zjištění, použití mikrovlnné technologie umožňuje při vytvrzování pojiv zkrácení vytvrzovacího procesu a současně vede k úsporám energie.

Nevýhodou použití mikrovlnných zařizení je problematické zajištění rovnoměrného rozložení energie při působení mikrovln. Vznik stojatého elektromagnetického vlnění je ovlivněno rozměry pracovní komory, frekvencí generovaných mikrovln i vlastnostmi ohřívaných předmětů. Průběh teploty se pro jednotlivé předměty liší dle jejich materiálového složení, rozměrů a aktuální teploty. Mikrovlnný generátor by však měl být schopný předměty zahřívat na vyšší teploty.

Další nevýhodou při využívání mikrovlnné energie je její odrazivost. Ta neumožňuje použití tohoto typu ohřevu u jakýchkoli materiálů obsahujících kovové součásti.

\section{Poděkování}

Tento výzkum byl projektem specifického výzkumu Vysokého učení technického v Brně NO. FAST-J-21-7238.

\section{Použité zdroje}

[1] Technologie a procesy sušení dřeva [online]. Mendelu - studijní materiály, 30. 09. 2013 [cit. 2021-06-28]. Dostupné z:

https://fraxinus.mendelu.cz/vyuka/soubory/TMZD_NMS/Povinne_predmety/Optimalizace_procesu_h ydrotermicke_upravy_dreva/PREDN_6.pdf

[2] SOBOTKA, J. a K. ŠUHAJDA. Likvidace biotických škůdců prostřednictvím EMW záření. In: Junior Forensic Science Brno. Brno: Vysoké učení technické, Ústav soudního inženýrství, 2012. ISBN 97880-214-4485-0.

[3] SOBOTKA, J. Účinnost likvidace biotických škůdců prostřednictvím mikrovlnného záření. In: Juniorstav. Brno: Vysoké učení technické v Brně, Fakulta stavební, 2012. ISBN 978-80-214-4393-8. 